\title{
PLURALIDADE E DIVERSIDADE DO HORIZONTE FORMATIVO NA PÓLIS CONTEMPORÂNEA: questão formativa
}

José Silvio de Oliveira*

Resumo: Este artigo aborda o sentido educativo e filosófico da pólis contemporânea. O objetivo foi refletir sobre a sociedade contemporânea tendo como referência a diversidade e pluralidade do horizonte formativo e existencial da pessoa humana. A própria natureza investigativa da pesquisa está baseada em estudos bibliográficos de caráter filosófico. Responde à questão sobre os valores e princípios fundados na tecnociência, na esfera do mercadológico, no mundo midiático, no mundo produtivo e, sobretudo, no âmbito político educacional.

Palavras-chave: Pólis contemporânea, Formação e Filosofia.

\section{PLURALITY AND DIVERSITY OF THE TRAINING HORIZON IN THE CONTEMPORARY}

\section{POLIS: a formative question}

\begin{abstract}
This article addresses the educational and philosophical sense of the contemporary polis. Our aim was to reflect on contemporary society with reference to the diversity and plurality of the training and existential horizon of man. The investigative nature of this research is based on bibliographical studies of philosophical character. It answers the question about the values and principles based on techno-science, in the marketing sphere, the media world, the productivity world and, especially, in the educational political sphere.
\end{abstract}

Key-words: Contemporary polis, Training and Philosophy.

\footnotetext{
* Doutor pelo PPGE da UFSCar, bolsa Capes, na Universidade de Coimbra, Portugal. Mestre em Educação, UFG, Especialista em Comunicação Social, USF, Licenciado em Filosofia FEBE, SC, Formando administração Cooperativas Rurais, pela UFLA. Professor Adjunto da UAE/EDU da UFG/REJ. Editor da Revista Itinerarius Reflectionis dessa mesma instituição. E-mail: oliveirajose354@gmail.com
} 


\section{Introdução}

Movida pela conexão globalizada, pelo mundo do eletrônico, pelo mundo das ciências, sobretudo pela cultura da imagem, do selfie, do fitness, do simulacro, do espetáculo, a sociedade atual em sua concretude avança para o futuro feito um foguete assaz acelerado. Abertamente o debate sobre a modificação de nosso genoma é algo corriqueiro no meio científico. Talvez as escolas brasileiras estejam ainda distante dessa questão. Ao contrário, na sociedade da informação e da técnica, isso não é novidade. Um exemplo claro disso é o de Josiah Zayner, (do qual é divulgado por meio de seu canal de YouTube, intitulado Josiah Zayner que possui aproximadamente 5733 inscritos), Doutor em biofísica pela Universidade de Chicago, podemos conferir no canal que ele mostra como modificar ou inserir genes no teu genoma. This is by no means meant to be a comprehensive guide and is instead meant to show people the ease at which CRISPR-Cas9 can be used to modify the adult human genome. (ZAINER, 2019.) Sem paradigmas ou, cheia deles, a sociedade contemporânea, atrelada ao mundo da internet, dos androids, dos tablets, dos smartphones, aliada ao poderio da ciência e do mercado, produz, na esfera educativa, uma formação difusa, incontida. Conduzido pela tecnologia e pela cultura da imagem, do som, da mídia, o indivíduo humano, parece, cada vez mais, fazer a experiência de seu próprio anonimato. Apesar dos privilégios das novas descobertas e do conforto produzido pelo mundo da produção e da ciência, esse horizonte aprofunda as desigualdades sociais, ignora o sentido da liberdade e da autonomia do homem.

Contemporaneamente modificamos o nosso estilo, o jeito de assistir televisão, de locomover, de comunicar, de passear, de ler um jornal, mudamos tudo, não existe uma esfera na sociedade que não foi tocada como a onda das novas tecnologias e mídias, entretanto, parece que a escola permanece estacionada como carro danificado. (OLIVEIRA, 2018, p. 2)

Do ponto de vista da engenharia genética não é necessário um laboratório ultra avançado ou mesmo ter um conhecimento altíssimo para mover nossa genoma. Explica na citação abaixo, basta que adquirir a proteína cas9, que vai cortar seu DNA no ponto em que você vai modificar ou inserir um gene. O cas9 podemos afirmar que é um instrumento, que, em certo sentido, configura o nosso genoma - informações hereditárias contidas em nosso genoma, logo o cas9 consiste em dois componentes, o primeiro da transcrição e o segundo o do locus, que resulta em curtos fragmentos de RNA com capacidade de desempenhar o reconhecimento de um DNA exógeno.

CRISPR-Cas is a system with a terrible name that contrary to popular belief does not actually do any genetic engineering or modification of DNA bases directly. Instead, the system uses a trick that has been well known in genetic design for many many years. It cuts DNA. Yep, that's all Cas9 does is cut DNA. See when DNA is damaged or cut most all organisms start to do DNA repair and this can end in one of three ways 1) The DNA is repaired perfectly and everything is ok 2) The DNA is repaired but some mistakes happen leading to problems translating the gene into protein because of frame shifts or mutations 3) The DNA is repaired using a template artificially supplied that 
results in a completely new sequence. When using CRISPR people aim to make use of (2) or (3) but most of the time when people talk about CRISPR they usually just mean (3) but not always.

Essa realidade é essencial para pensarmos a realidade de nossas escolas, essas informações abalam e estão longe dos currículos das escolas, não existe um direcionamento para entender essa questão. Não é novidade afirmar que o universo educativo em grande parte ficou reduzido ao horizonte escolar. Esse, por sua vez, ao mundo das contas e das estatísticas. Esse universo escolar reduzido ao mundo do Exame Nacional do Ensino Médio - Enem. Em muitos sentidos a sociedade contemporânea nega os processos de formação e de humanização da existência coletiva e pessoal. Sem rumo e sem identidade, cada vez mais, o homem escorrega no vazio de seu próprio individualismo.

Nesses últimos anos o debate sobre a formação integral do ser humano aumentou consideravelmente. A questão da formação do homem atual é um dos maiores problemas a ser pensado em nossa atualidade. No entanto, essa questão está longe de ser resolvida, já que, é um problema cultural, histórico, sociológico, psicológico, filosófico, educacional. Em suma é um problema político de primeira grandeza. Nesse âmbito, o processo educacional também se tornou uma crise, sobretudo nas sociedades ocidentais modernas. Em toda parte, seja qual for o país o problema formativo se manifesta assumindo formas diversas. O debate formativo segue por trilhas incontidas: como pensar a formação tecnológica e produtiva? Como pensar o caráter formativo e ético do homem? Como pensar neste contexto o homem máquina - ciborgue? Aliás, quase todos nós, nossos filhos e filhas estão conectados permanentemente ao mundo dos circuitos elétricos. Donna J. Haraway (2009) afirma:

A ficção científica contemporânea está cheia de ciborgues - criaturas que são simultaneamente animal e máquina, que habitam mundos que são, de forma ambígua, tanto naturais quanto fabricados. A medicina moderna também está cheia de ciborgues, de junções entre organismo e máquina, cada qual concebido como um dispositivo codificado, em uma intimidade e com um poder que nunca, antes, existiu na história da sexualidade. (p.36.)

Ao reportar ao momento amplo que a sociedade contemporânea atravessa, podemos afirmar que, o cenário histórico-social expressa uma verdadeira crise de sentido e de significações acerca da formação humana. Do ponto de vista político, “A aproximação entre a análise do Estado e a educação também orienta-se por este pressuposto de representação simbólica e repressiva.” (Nunes, 1999, p.71). Não podemos negar que, nos últimos trinta ou quarenta anos a vida e a existência humana se complexificou abundantemente em todos os sentidos. Não há sequer um lugar do mundo que não tenha sido abalado com as criações e invenções da natureza do mundo técnico-científico desses últimos anos.

Não há sequer uma mínima amostra da vida social, econômica, ética e política que não tenha sido modificada. Pensar esse sentido impõe-se uma tarefa peculiar, o âmbito formativo contemporâneo é amplo. Pensar sua gênese e sua natureza é sem dúvida perguntar pela especificamente 
política educacional que gera e alimenta a sociedade atual. Na verdade, perguntar pela formação do homem contemporâneo é indagar pelo sentido das políticas contemporâneas advindas do Estado.

É neste labirinto que teremos que trilhar, ainda que não se consiga vislumbrar seu norte, é por ele e nele que se procura desvendar as armadilhas teóricas e científicas no campo das humanidades. Não existem soluções prontas e nem fórmulas mágicas. A pluralidade da formação e a diversidade pedagógica foram e são constantes na história da educação humana. A questão da diversidade não é uma interrogação propriamente do mundo contemporâneo. Sobre isso, expressou o filósofo Immanuel Kant: “Com a educação presente, o homem não atinge plenamente a finalidade da sua existência. Na verdade quanta diversidade no modo de viver ocorre entre os homens." (1986, p.17). A questão da formação do homem atual é um dos maiores problemas a ser pensado em nossa atualidade. No entanto, essa questão está longe de ser resolvida, já que, é um problema cultural, histórico, sociológico, psicológico, filosófico, educacional. Em suma é um problema político de primeira grandeza. A formação humana da contemporaneidade é marcada pela ênfase dada à ciência, à mídia, à tecnologia, ao conhecimento, à política, e ao mundo econômico. Neste território sem referências ou, cheio delas, a pergunta que impulsiona e revela o problema deste artigo é traduzida na seguinte interrogação: como pensar o sentido formativo da educação e da escola? É nessa trilha, portanto, que nossa investigação caminha. Metodologicamente a proposta e objetivos da pesquisa deste artigo estiveram vinculados ao estágio doutoral sanduíche ocorrido no Centro de Estudos Clássicos e Humanísticos da Faculdade de Letras da Universidade de Coimbra em Portugal entre os meses de janeiro a setembro do ano de 2014. A pesquisa teve caráter bibliográfico.

\section{A questão filosófica}

Já afirmamos, a pólis da contemporaneidade é a cidade dos softwares e dos hardwares, dos androids e dos tabletes, dos selfies, é a civilização da comunicação e da globalização da informação conectada, portanto, estamos a falar de uma sociedade da conexão, sobretudo, a civilização do genoma. Essa dinâmica conceitual que identifica a nossa pólis atual coincide com a integração dos fenômenos econômicos e tecnológicos. A conjuntura mundial ganha novos espaços e novos horizontes de reflexão, sobretudo com as novas configurações do mundo geopolítico aliado ao mundo da máquina. O mundo do individualismo, do particular, da competição gera e alimenta cada vez mais as desigualdades entre os grupos humanos. Parece reinar como humano, à imagem, à representação, o simulacro, o espetáculo, o efêmero, o banal, ao inverso, a mulher e o homem, a criança e o jovem são confundidos e identificados como coisa, mercadoria ou produto.

A sociedade portadora do espetáculo não domina somente pela hegemonia econômica as regiões subdesenvolvidas. Domina-as enquanto sociedade do espetáculo. Onde quer que a base material ainda esteja ausente, a sociedade moderna já invadiu espetacularmente a 
superfície social de cada continente. (DEBORD, 2012, p.34)

Por um lado, não é novidade afirmar que a antropologia do homem passa a ser questionada. O humano está conectado ao mundo da cibernética. É o mundo da instrumentalização da razão, como escreveu Marx Horkheimer, (2001). É o mundo das incertezas e dos extremos como expressou Eric Hobsbawm, (1995) É mundo do espetáculo como atestou Guy Debord, (2012). É o mundo da insignificância, conforme pensou Cornélius Castoriádis, (2002). É o eterno mundo admirável de Aldous Huxley, (1937). É acima de tudo, o mundo da técnica e, fora dela, parece não haver outra coisa mais importante. Desde os tempos de Descartes (1596-1650) forjou-se a era do mecanicismo. Somandose também a isso, o know how moderno parece pôr em dúvida o próprio sentido da filosofia, da educação, da escola, das artes, das letras e da cultura e, portanto, da formação humana. Por outro lado, em sentido geral se pode dizer que a vida passa a ser ordenada autonomamente, sem estabelecer vínculos com o mundo e com a cultura passada. Perde-se o sentido de história e também o sentido e o entendimento da natureza.

Essa dupla perda do mundo - a perda da natureza e a perda da obra humana no senso mais lato, que incluiria toda a história - deixou atrás de si uma sociedade de homens que, sem um mundo comum que a um só tempo os relacione e separe, ou vivem em uma separação desesperadamente solitária ou são comprimidos em uma massa. (ARENDT 2002, p.126)

Diante da crescente e gradual alienação do mundo, Hannah Arendt (2002) entende que os conceitos de história e natureza foram abolidos, e esse rompimento com as questões tradicionais, no campo político e moral, revela uma lacuna entre o passado e o futuro, aumentando sempre mais o relativismo formativo. A separação entre público e privado é visível no âmago de toda a sociedade. As ideias de política, civilidade, cidadania, educação, escola, formação, ensino, aprendizagem, docência, cada vez se entrelaçam, se transmutam e se complexificam em torno do dinheiro e das novas invenções. O mercado, a economia e, portanto, o poderio das grandes empresas e da hegemonia de uns poucos poderosos, reduzem o sentido de educação e da escola. Cada dia mais, a ideia de competição é reforçada, é descomedida em todos os sentidos da vida social. A própria ideia de escola é colocada em xeque, exatamente por aqueles que por ela um dia passaram. A pólis atual parece não mais fazer distinção entre o espaço formativo individual e o espaço educativo público. Ficam separadas e desintegradas tais dimensões.

Do ponto de vista da reflexão, do pensamento filosófico, a dimensão entre o pensar e o fazer parece desconectada. A era da técnica há muito abandonou a filosofia - o sentido do pensar, em larga medida, as ciências que atuam no plano do humano. As humanidades, as letras, a filosofia, as artes, a educação, são realidades que pouco valem nesse labirinto instrumentalizado, entretanto é preciso filosofar: é preciso fazer distinções entre a educação e a escola, mais que isso, é preciso separar a essência 
educativa da escola, entendendo-a não como “[...] coisas, realidades existentes em si e por si mesmas, mas acontecimentos, processos que estão se constituindo nas relações que os homens criam e recriam, [...]" (COÊLHO, 2001, p.63) e a aparência da realidade, que se apresenta como imutável, pronta, acabada, como imagem, simulacro ou representação. Portanto, é preciso separar o espetáculo da realidade. O fenômeno educativo dependente ao devir histórico e radicado nas formas concretas de existir e pensar as diferentes épocas históricas é inseparável de seu caráter histórico e cultural.

Nas declarações, nas leis, nos projetos políticos, a educação contemporânea é vista e contemplada em primeiro lugar, mas, no plano da realidade concreta, fica relegada. O Estado atual, quando aliado às grandes empresas, à transforma numa espécie de serviço de quem aprouver. Parece que a educação, em sentido amplo, não é percebida. Reduzida à escola, se transformou num bem privado, um negócio disputado no mercado. A sociedade moderna vende e compra educação entendida como escola, como ensino. O mundo contemporâneo trafica o sentido da escola, a natureza do ensino e a finalidade da aprendizagem e, portanto, nega a maioria da população, mias que isso, o saber socialmente reduzido ao plano da instrumentalização os jovens, as crianças, os homens e mulheres são entregues à lógica hegemônica do império do mercado. Isso é visível, basta perceber as escolas públicas. Na era das certezas das técnicas, das novidades tecnológicas, do poder das ciências, da sociedade do espetáculo, da imagem e da mídia, da informática e da hegemonia mercadológica uma pergunta sustenta este artigo: o viés político que emana paideia filosófica expressa teoricamente princípios universais que válidos quando pensamos numa escola de Estado com finalidade única, cujo processo pedagógico possibilite uma formação omnilateral de crianças e de jovens, de homens e de mulheres de nossa sociedade?

A questão do ensino é uma proposta mundial. Isso não é mais novidade para quem quer que seja. Nunca a educação foi tão contemplada e lembrada como agora: teoricamente, está nas constituições dos países, é pauta primeira nas declarações e nos documentos das associações, dos sindicatos e das organizações privadas ou estatais. Uma das principais agências é a UNESCO, (United Nations Educational, Scientific and Cultural Organization), associação que atua embaraçosamente a partir da ideia de cooperação. O próprio Banco Mundial (BM) atua como órgão privado para prover recursos financeiros aos países membros. Há pouco mais de duas décadas na Tailândia, em consonância com a UNESCO, precisamente em 1990, na cidade de Jomtien, aconteceu a conferência sobre a educação para todos, dali surgiu a mais expressiva declaração sobre os direitos da educação e do ensino: $A$ Declaração Mundial sobre Educação para Todos: satisfação das necessidades básicas de aprendiragem. Dali, surgiram muitas políticas e distintos compromissos mundiais a serem cumpridos. Um deles é garantir, a todas as pessoas, o direito de receber os conhecimentos básicos necessários a uma vida digna. Em conformidade com a promulgação da nova Lei e Diretrizes e Bases em 1996, o Brasil, de lá pra cá, tem insistido em dar continuidade a tal proposta. Podemos ler nas Disposições Transitórias, no título IX, está escrito no artigo 87, parágrafo primeiro: “A união, no prazo de um ano, a partir da publicação dessa lei, encaminhará ao Congresso Nacional, o Plano Nacional de Educação, com diretrizes e metas para os dez anos seguintes, 
em sintonia com a Declaração Mundial sobre Educação para Todos.” (BRASIL, 2014).

Nessa época, o Ministério da Educação não apenas considerou a $A$ Declaração Mundial sobre Educação para Todos, de Jomtien, mas todos os compromissos e recomendações internacionais, entre eles a Conferência Internacional sobre População e Desenvolvimento (Cairo, 1994), a Cúpula Mundial para o Desenvolvimento Social, a Declaração de Hamburgo sobre Educação de Adultos (1997), as Declarações de Nova Delbi e a Declaração da Amann (1993 e 1996, respectivamente), e outras tantas que vieram depois. Mundialmente, está contemplada nos planos dos Estados e dos municípios, a educação é tema prioritário nas campanhas políticas, é o alvo certeiro nos discursos controversos de políticos e de candidatos. Está nos temas dos mais diferentes congressos, seminários e encontros. As preocupações são intensas, seja do ponto de vista do acesso à escola, da qualidade do ensino e da aprendizagem, das condições de igualdade de oportunidades, da gratuidade, seja do ponto de vista da diversidade, da inclusão e da exclusão, da seletividade, em suma: em teoria, a educação está em toda parte, e é também nossa preocupação.

Colocar em questão o significado da educação, bem como, investigar o sentido da dimensão educativa da escola e do trabalho que essa realiza, podemos perguntar: o que tem prevalecido como meta e prioridade na sociedade contemporânea, o sentido de educação entendida como paideia, cultura, formação humana integral ou o sentido da racionalidade instrumentalizada do monopólio do mundo produtivo? O que se privilegia não é a escola entendida como lócus de criação e invenção de cultura de humanidades, de artes, de letras, de dança, de música, do teatro, mas sim, lócus de plágio, de cópia e repetição, de violência, de indisciplina, de intrigas políticas, portanto, é muito mais lócus de desequilíbrio educativo, do que propriamente espaço de conhecimento, de formação verdadeira e de saber. O que tem prevalecido não é a educação em seu sentido amplo. A técnica, a ciência, o poder do mercado e das grandes empresas reduziram o sentido da educação à escola. A educação está fragmentada e reduzida ao mundo das estatísticas, dos números, das notas, do desempenho, dos cursinhos, do resultado final, do provão, dos antigos vestibulares, portanto, do Enem (Exame Nacional do Ensino Médio) - do provão Enade (Exame Nacional de Desempenho dos Estudantes), ou seja, do treinamento, do pontual e do efêmero, da eficiência, da técnica e do consumo. A própria dimensão educativa do ensino superior está atrelada ao mundo produtivo: o ensino, a pesquisa, e a extensão são realidades que, além de fragmentadas, estão reduzidas também ao plano do comércio e das grandes empresas.

Gabam-se as estatísticas: do equilíbrio na quantidade de matrículas em todas as etapas da educação básica; das matrículas no ensino superior; da redução da taxa de analfabetismo; da oferta da qualidade do ensino público e privado do Brasil; da taxa de frequência às creches brasileiras, e, portanto, demonstra que os objetivos estabelecidos no Forum Mundial em Dakar - Senegal, em 2000 - cuidados na primeira infância e na educação foram metas que hoje o país avança.

Gabam-se os números em Estudos \& Pesquisas Informação Demográfica e Socioeconômica, no 27 - Sintese dos Indicadores Sociais. Uma Análise das Condições de Vida da População Brasileira, 2010, o Instituto Brasileiro de Geografia e Estatísticas (IBGE), em 2009, identificou pela Pesquisa Nacional por Amostra 
Nacional de Domicílios (PNAD) mostrou que: “[...] o grupo de crianças de 0 a 5 anos de idade apresentava uma taxa de escolarização de 38,1\%, enquanto em 1999, essa proporção era de apenas 23,3\%.". (IBGE, 2010). O ano de 2000 até o ano de 2010, de acordo com o IBGE, o número de analfabetos correspondia a 13,63 \% da população (quinze anos ou mais de idade). Este índice caiu para 9.6\% em 2010. Contudo, a meta proposta para o Brasil, em consonância com um acordo estabelecido pela UNESCO, espera terminar o ano de 2015 com uma redução de ate 6,7\%. Ao final da introdução do tema: educação, a síntese dos indicadores numéricos revela:

Sem dúvida, o País alcançou nas últimas décadas um crescimento substantivo quanto ao acesso à escola, especialmente em relação à educação infantil. Em 2009, a Pesquisa Nacional por Amostra de Domicílios - PNAD mostra que o grupo de crianças de 0 a 5 anos de idade apresentava uma taxa de escolarização de 38,1\%, enquanto em 1999, essa proporção era de apenas 23,3\% (IBGE, 2010)

O Instituto Nacional de Estudos e Pesquisas Anísio Teixeira notifica os resultados obtidos pela UNESCO: o modelo de financiamento da educação básica do Brasil é destaque no Relatório de Monitoramento Global de Educação para Todos 2013-2014. O documento confirma que, nas últimas décadas, os recursos financiados e redistribuídos, as reformas educacionais que foram realizadas, sem dúvida, são fatores que marcam a redução das diferenças regionais das nossas escolas. O ponto de referência foi o Fundo de Manutenção e Desenvolvimento da Educação Básica e de Valorização dos Profissionais da Educação (FUNDEB)

Entre 2007 e 2012 o valor arrecadado passou de R \$ 46,6 bilhões para R \$ 106,6 bilhões. Ainda por meio do Fundeb, foram repassados, a título de complementação, para as redes de ensino, recursos da ordem de R \$10, 4 bilhões, em 2012. Em 2007, este valor foi cinco vezes menos, com $\mathrm{R} \$ 2$ bilhões. (INEP, 2014)

Entretanto, as inadequações organizacionais do Estado, cada vez mais, perpetuam e evidenciam a desigualdade. Da mesma forma é visível o baixo nível da qualidade do ensino e da aprendizagem na escola, por mais que neguem a face excluída e oprimida, tanto mais salta aos olhos. Os filhos dos trabalhadores ainda não vivem verdadeiramente uma escola pública e de qualidade. Aliás, a escola que receberam manteve sempre um viés tecnicista e unilateral. Em sua época, Karl Marx já tinha entendido isso.

É preciso reconhecer que o nosso trabalhador sai do processo de produção diferente do que nele entrou. Depois de concluído o negócio, descobre-se que ele não era 'nenhum agente livre', de que o tempo que dispõe para vender sua força de trabalho é o tempo em que é forçado a vendê-la, de que em verdade, seu explorador não o deixa 'enquanto houver ainda um músculo, um tendão, uma gota de sangue para explorar'. (1985, p.237).

Isso na verdade é ainda um resquício e herança da educação grega: a grande maioria não 
precisa de escola, basta um treinamento para aprender a trabalhar. Os dirigentes da escola pública, sobretudo, nós pesquisadores, professores, muitas vezes não distinguimos a escola pública do movimento da ação estatal. A nossa escola pública ainda padece nas mãos de homens e de mulheres incapazes de perceber o que se passa com a educação e com a escola, portanto com a sociedade. Eles ou nós confundimos o sentido da educação com o da escola. Nós sabemos muito bem que a escola brasileira sempre esteve amarrada aos desdobramentos históricos, e políticos e, sobretudo, à interesses de poucos. Isso é histórico no Brasil. "Em 1988, foi encaminhado à Câmara Federal um projeto de lei que propunha a fixação das diretrizes e bases para educação nacional, que, em 1989, foi substituído por um outro." (ASSIS, 2013, p.41) De acordo com a autora, posteriormente, o projeto encaminhado pelo senador Darcy Ribeiro em 1992 só foi aprovado seis anos mais tarde pela Lei n 9394. Não é necessário voltar às origens de nossa escola brasileira para afirmar que ela é elitista, excludente e autoritária.

O próprio Plano de Desenvolvimento da Educação (PDE) em 2007, cujas raízes cruzam o limiar de 2020, que foi lançado pelo Ministério da Educação deveria fazer valer sua meta: ou seja, enfrentar o problema dos níveis da qualidade do ensino ministrado para todas as escolas da educação básica do país, entretanto, o tiro saiu ao contrário. A questão volta a ser uma questão técnica, ou seja, o que importa são os números. Expressa Demerval Saviani: “Mas o 'Plano', se mostrou bem mais ambicioso, agregando 30 ações que incidem sobre os mais variados aspectos da educação em seus níveis e modalidade.” (2014a, p.1232) De acordo com as considerações desse autor, essa é uma iniciativa de natureza contábil. A questão pode realmente trazer um ganho de gestão, porém não representa um ganho financeiro. Ele explica, “[...] podem melhorar o financiamento da educação comparativamente à situação atual, mas não terão força para alterar o status quo vigente." (Saviani, p.1249). O aumento considerável de matrículas é desproporcional ao número de professores, daí, cada vez, a precariedade do trabalho do docente. O discurso hegemônico de uma escola produtiva é vazio e inútil. A tentativa da política contemporânea em traduzir os conceitos de competência e habilidade para os moldes de uma formação omnilateral não passa de uma indiscutível jogada mercadológica. Na mesma linha de direção de Dermerval Saviani, Ildeu Moreira Coêlho contesta a instrumentalização da escola, a partir de uma pedagogia de resultados e, defender uma escola produtiva, “[...] está longe da lúcida compreensão dessas realidades e da criação de uma educação e escola que visem a superá-las.” (2012, p.15)

A crise da educação que trata Hannah Arendt em seu livro Entre o Passado e Futuro não é uma crise propriamente dos países do sul ou dos países menos desenvolvidos, visto que é uma crise propriamente dos países do sul ou dos países menos desenvolvidos, é uma crise estrutural que perpassa todas as nações. Essa política produtiva é visível, ela desorienta e não configura a lógica e o equilíbrio do educativo. No interior de nossas escolas, seja nos corredores ou nas reuniões pedagógicas, nos encontros seminários e congressos, a ideia de produtividade é constante. De tanto olhar para a escola, esquecemonos da finalidade para qual foi criada.

A ideia - conceito de produção é uma ideia que cotidianamente circunda a vida, a cultura, 
a sociedade do povo brasileiro. Não é um modismo, mas um hábito. Aristóteles diria em outras palavras, acostumamos e criamos o nosso fazer, do nosso falar. As palavras originais: do Estagirita: "[...] o homem é o originador de e gerador de suas ações [...].” (ARISTÓTELES, 2001, p.57) Parece que perdemos a noção de humanidade, incorporamos o discurso do prático, das coisas, do mercado, e da técnica. Os filósofos da contemporaneidade filosofam atualmente sobre o mundo pós-humano. Sem dúvida, precisamos filosofar sobre tudo. Nada pode escapar à reflexão. Mas, inverter as prioridades nesse contexto é, contudo, esquecer novamente a originalidade para qual a escola e a educação foram criadas. Continuamos com o discurso da hegemonia científica e tecnológica em primeiro lugar. A realidade da sociedade e da escola brasileira são exemplos disso ao longo de sua história. A seletividade, a exclusão e a opressão são marcas indeléveis que sofreram e sofrem as camadas populares. A discriminação que padeceu e padece os grupos minoritários é também realidade viva e contraditória nesta sociedade. Expressa Cesar Nunes, “[...] a educação e a escola brasileira ainda ressentem-se de uma pedagogia e espectro institucional eficiente voltado para a qualificação e capacitação das amplas maiorias.” (1999, p.72) O lócus público tornou-se palco e demanda de negociações mercadológicas de grandes empresas, muitas vezes, acordados com o próprio Estado. Da educação infantil até a educação superior, as nossas políticas públicas são racionalistas, tecnicistas, portanto, produtivas.

Enfatizando a educação superior no âmbito do desenvolvimento econômico brasileiro e a própria política pública que se desprende das malhas do governo, a pesquisadora Marcia Santos Anjo Reis, especificamente, entre os anos de 1995 a 2010, evidencia que os ex-presidentes, Cardoso e Lula da Silva, cada um à sua forma, "[...] aceitam como problemas da educação superior o reduzido quantitativo de matrícula, a baixa relação professor/aluno, a baixa qualidade de cursos de graduação, [...]”. (2013, 62) Os problemas financeiros da educação ficam visíveis, são muitos, mas, a forma de encarar as questões, em certo sentido, não se difere. O traço de continuidade é constante, embora, existam rupturas.

[...] fica visível na formulação legislativa em favor do modelo de expansão da educação superior pela iniciativa privada, que tem o Programa Universidade para Todos (Prouni) como sua maior extensão. Por outro, lado o traço de ruptura consubstancia-se no retorno da União como protagonista da educação superior, traduzido no crescimento intensivo das Ifes. (Reis, p.62).

A pólis contemporânea negocia o que é de todos, trafica o que é da comunidade. $\mathrm{Na}$ verdade, rouba e delibera em favor de poucos. A política educacional é exemplo perfeito desse tráfico. Já descrevemos e vamos repetir: a educação contemporânea há muito deixou de ser entendida como direito de todos, ao contrário, é entendida como serviço, não importa se é privado ou público. A educação deixou de ser um direito de todos, aliás, nunca foi. "A grande maioria da população mundial não é sujeito de direitos humanos. É objeto de discursos de direitos humanos." (Santos, 2013, p.13) O sistema educativo contemporâneo não tem uma finalidade única. Não visa o interesse do bem comum.

O nosso ágora contemporâneo parece se agravar. Afirmamos em muitas outras 
oportunidades esta questão. O espaço - o lócus público contemporâneo, ou, mais precisamente, as relações humanas, parece se dinamizar em espaços vazios: "vazios de pessoas, de sentidos e, portanto, de relações e aprendizagem significativas”. (Pereira, 2011.p.31) Não se sabe bem ao certo o que é público e o que é privado. Há uma confusão geral nesse sentido. Nessa confusão generalizada, podemos perguntar: quais são os espaços públicos? O autor Amarílio Ferreira Junior e a autora Marisa Bittar afirmam:

O agravante, além disso, é o domínio do capital sobre todas as relações sociais em escala jamais vivida pela humanidade, coisificando os próprios homens, o que exige de nós reflexões urgentes e cada vez mais complexas, inclusive nas salas de aula e na convivência com os nossos alunos, pois a escola, neste momento de reestruturação produtiva do capitalismo, está se ajustando aos ditames do mercado e se convertendo cada vez mais, no espaço do não conhecimento e do esvaziamento de seu sentido. (2014, p.639).

Essa realidade contemporânea não é apenas uma realidade brasileira ou, mais especificamente, da educação no Brasil. Os direitos coletivos - comum - de todos, parecem entrelaçados a milhares de interesses. Qual é o lócus dos direitos humanos? Quando Boaventura dos Santos, um dos mais brilhantes investigadores portugueses, se refere aos direitos humanos contra hegemônicos, diz, em sentido amplo, que "[...] só podem ser imaginados como lutas contra o sofrimento humano injusto, concebido no sentido mais amplo e abrangendo a natureza como parte integrante da humanidade." (Santos, 2013, p.104).

O caminho da cibernética, da eletrônica, da ciência, da técnica faz parte do labirinto do futuro. O ciborgue é uma realidade: não temos como retroceder. Deverá ele traduzir o caminho das humanidades? De que modo? Não se pode negar que criamos necessidades, das quais nos tornamos reféns. Aproximamo-nos de uma margem infindável de problemas e questões. As relações humanas são relações complexas, a própria condição humana uma condição também complexa e, sobretudo, sensível. Daqui brotam sentimentos, valores, lutas, dores, sofrimentos, poder, hegemonia, ganância, individualismo, relativismo. As instituições públicas, especialmente o sistema educativo contemporâneo, a cada dia mais se entrelaçam e se estreitam no mundo da técnica, da ciência, do poder, das crenças, da subjetividade, das identidades, e de todos os tipos de modismos e particularidades. Tal ocorre no sistema educativo, não apenas no sistema de ensino brasileiro, mas em escala mundial. Não existe país ou nação que não contemple essa dimensão da privacidade atrelada ao mundo público. O mundo privado ocupa o lócus do público.

A pólis ideal civilizacional pretendia articular a cidade à urbanidade como virtude de civilidade, no nosso tempo a cidade, submetida que está à fragmentação dos espaços e à despolitização enquanto espaço público ou à colonização dos espaços pelos diferentes poderes e pelos interesses econômicos, não nos permite mais uma correspondência entre espaço-cidade, e aquilo a que podemos chamar espaços de relações humanas. (PEREIRA, 2011, p.31).

Este espaço formativo ou, esta situação pode perfeitamente bem ser totalmente 
preenchida por objetos de interesses que esgarça as relações entre os homens. Os nossos problemas de educação são muitos, porém, o mais grave é não distinguir um e outro. Portanto, fazer filosofia é, sobretudo, fazer distinções. "Escrevemos e falamos 'educação', mas lemos e entendemos 'escola ." (COÊLHO 2001, p.55) O problema não é apenas a escola, como têm pensado alguns. Grande parte das políticas do Ministério da Educação tenta resolver os problemas da escola e as coisas da escola. Nossas crianças e jovens não são números, e isso já estamos cansados de enfatizar.

\section{À guisa de conclusão}

Não importa o caminho histórico que temos percorrido, não importa a trilha percorrida até agora pela civilização educativa: queremos, aos poucos, caminhar para frente, não para os lados, e muito menos retroceder. Dermeval Saviani, ao avaliar o último Plano de Desenvolvimento da Educação, para o Brasil, comenta positivamente as ações do Ministério da Educação e da Cultura, no seu entendimento, é “[...] positiva a iniciativa do MEC de capitalizar a receptividade da opinião pública à questão da qualidade do ensino [...]”. (2014b, p.1251) É inegável que ele considerou o ufanismo dos empresários brasileiros. Diante dos empresários, diante da tão sonhada e proclamada Educação para Todos, podemos ler:

Inegavelmente, é preciso aproveitar esse momento favorável, em que a sensibilidade em torno da importância e prioridade da educação se espraia pela sociedade e parece exigir que se ultrapasse o consenso das proclamações discursivas, e se traduza em ações efetivas. No entanto, é preciso cautela para não cairmos na ingenuidade de acreditar, sem reservas, nas boas intenções que agora, finalmente, teriam se apoderado de nossas elites econômicas e políticas. (SAVIANI p.1251).

O sentido formativo do homem, da mulher, das crianças e dos jovens não são instrumentos mágicos, menos ainda são mercadorias a serem trocadas e vendidas ao longo do lócus público. O passado é o passado. O presente é o presente, e o futuro é o futuro. Por seu viés, em República, o filósofo Platão nada mais quer que o homem ou a mulher se converta à educação. Não é nada mais do que isso. Isso jamais é passado: é atualíssimo. Converter-se à educação é a ela se entregar, em sua amplitude. Immanuel Kant afirmou: “Uma geração educa a outra.” (2002, p.12) Educação não é somente escola, mais que isso, no Werner Jaeger (2001), revelou em sua magnífica obra, Paideia, A Formação do Homem Grego, que, a paideia é a verdadeira forma da educação do homem, aqui, reside o substrato mais significativo do ponto de vista humano. Ao mesmo tempo, em que modela apropriadamente o formato do ser humano, dinamiza e orienta a riqueza, e a complexidade da existência do homem. Portanto, é civilização de cultura, de artes, de letras, de humanidades: é a expressão de formação mais profunda da omnilateralidade humana. A escola que estamos a defender é uma escola que garanta a igualdade para todos: o filho do rico deverá sentar-se na mesma cadeira que o do trabalhador; que o pobre e o rico estejam juntos, na mesma sala. Não nos estamos referindo a uma escola estatal, do governo, e gerida 
somente por este e por interesses empresariais. Não estamos falando de uma escola unilateral. Estamos falando de uma formação omnilateral.

Não é necessário afirmar que a escola pública é ser de todos, e deve visar a melhor formação possível dos homens uma cidade. Do ponto de vista social e, sobretudo, todos nós desejamos que os indivíduos desempenhem sua função social da melhor forma possível, visando atingir o bem da cidade: realmente, todos devem possuir a bondade do bom cidadão. Essa é a condição única para que a cidade seja melhor. Qual legislação poderá legislar em proveito de outras? Sabemos perfeitamente bem que a escola pública, diga-se de passagem, não forma alunos em igualdade de oportunidades. "Os direitos culturais centram-se no direito à identidade, à educação, a informação, à participação na vida cultural, portanto, à diferença cultural, ao acesso a práticas culturais.” (Pereira, 2011, p.22) O nosso ethos cultural é historicamente desafinado e sem tonalidade expressiva. Nós não aprendemos o sentido educativo em sua amplitude. Não se resgata ou se recupera um estilo ou um modelo de vida após se ter, por longos anos, adquirido outros hábitos. "A qualidade da educação consiste em recuperar a nossa pertinência cultural, recuperar a capacidade de inovação e mudança que define a cultura científico-tecnológicocontemporânea." (Nunes, 1999, p. 61.) O ethos é construído ao longo do tempo, pela educação e na história política, na legislação de um povo. A nossa educação não é pensada com crítica e com contestação, longe disso, o sentido político, social, individual, cultural e o próprio fim vital pertencente a ela, fica em segundo plano.

Institucionalizar a educação em nome de uma escola para poucos é traficar seu verdadeiro sentido. Por isso, nossa defesa ao Estado e à escola pública. Não uma escola preparatória e instrumental, fundada em interesses privados ou empresariais, mas uma escola que cria e inventa humanidades. Parece que a escola da contemporaneidade deixou de ser um espaço de pensamento, de filosofia, de reflexão.

Numa sociedade concebida e marcada pelo mundo da imagem, do som, do imediato, do sensível, da utilidade prática, da efemeridade e rapidez das informações, do extremismo do mercado financeiro, da instrumentalização do ensino e da educação, a filosofia talvez pouco tenha a dizer. (OLIVEIRA 2015, p.314).

Sem projetos coletivos, esta era da cibernética, da máquina, da técnica, portanto da instrumentalização, implica cidadania e democracia utilitária, prática. Em outras palavras: a trama do tecer político educativo da contemporaneidade pode ser traduzida na era um prolongamento do niilismo técnico, individual, em favor do ciborgue do capital.

A subjetividade humana é, hoje, mais do que nunca, uma construção em ruínas. Ela já não tinha mesmo jeito, desde as devastadoras demolições dos "mestres da suspeita": Marx, Freud, Nietzsche, sem esquecer, é claro, Heidegger. A obra de desconstrução iria prosseguir, incansável, a partir de meados do século XX, com as operações de desalojamento do cogito cartesiano efetuadas pela revisão althusseriana de Marx e pela revisão lacaniana de Freud. Depois, com os pós-estruturalistas, Foucault, Deleuze, Derrida, Lyotard, o estrago se tornaria irremediável e irreversível. Sem volta. A point of no return. (HARAWAY, 2009, p.9) 
Por sua vez, Haraway, sem dúvida coloca uma questão gravíssima, queremos ou não se constituirmos como sujeitos? Do ponto de vista da formação humana isso é, acima de tudo, uma pergunta, que cedo ou mais tarde, somos obrigados a responder! No pensamento da investigadora portuguesa Paula Cristina (2011), a complexidade e a diversidade do mundo contemporâneo requerem, entretanto, da experiência do pensamento filosófico mais cuidado e maior atenção para não esgarçarmos e sucumbirmos aos debates e reflexões sem sentido, sobretudo, "[...] face aos discursos da crise e ao relativismo que podem fazer parceria com a irresponsabilidade, com a insensibilidade e, portanto, com a irreflexão.” (p.81.). Em larga e boa medida, a falta de lucidez formativa seja das ciências humanas, sociais, exatas, seja das ciências da técnica ou da tecnologia das artes e das letras, muitas vezes ignora o sentido amplo da formação humana. Expressa Saviani: "Cumpre restabelecer o primado do problema recolocando a educação no centro de nossas cogitações, isto é, como ponto de partida e de chegada das teorizações e práticas pedagógicas.” (1990a p.3) Nesse sentido, a reflexão formativa da filosofia fica vazia de referência, bem como a educação e a escola. Não é somente tarefa filosófica pensar a formação contemporânea, ou ainda sobre o homem pós-orgânico, isto é, o homem artificial, é também tarefa da antropologia, da sociologia, da psicologia, da política, e sem dúvida, da educação e da escola moderna.

\section{Referências}

ARENDT, Hannah. 2002. Entre o passado e o futuro. $5^{\mathrm{a}}$ ed., São Paulo, Perspectiva, 348 p. ARISTÓTELES. 2001. Ética a Nicômacos. $4^{a}$ ed., Brasília, UnB, 238 p.

ASSIS Renata Machado. 2013. Educação dos sete aos quatorze anos: A garantia legal do acesso à escola. In: ASSIS Renata Machado. Educação e cultura: diferentes dimensões. Curitiba: CRV, 212 p.

BRASIL. Lei $n^{\circ}$ 9.394/96, que estabelece as Diretrizes e Bases da Educação. Nacional. 1996. $<$ http://www.planalto.gov.br/ccivil 03/leis/19394.htm > Acesso 05/06/ 2015.

CASTORIADIS, Cornelius. 2002. As encruq̨ilhadas do labirinto. A ascenção da insignificância. São Paulo, Paz e Terra, 279 p.

COÊLHO, Ildeu Moreira. Filosofia e educação 2001. In: PEIXOTO, José Adão. (Org.). Filosofia, educação e cidadania. Campinas, Alínea, p.17-70.

DEBORD. Guiy. 2012. A sociedade do espetáculo. Lisboa: Antígona Editores Refractários, 137 p.

FERREIRA JR. Amarílio, BITTAR, Marisa. 2008. A educação na perspectiva marxista: uma abordagem baseada em Marx e Gramsci. Interface (Botucatu) [online]. 12, (26): 635-646. Disponível em: <http://www.scielo.br/scielo.php?pid=S1414-32832008000300014\&script=sciabstract\&tlng=pt > Acesso 05/06/2015.

HARAWAY, Donna J. Antropologia do ciborgue: as vertigens do pós-humano / organização e tradução Tomaz Tadeu - 2. ed. - Belo Horizonte: Autêntica Editora, 2009. - (Mimo). Disponível em: file:///C:/Users/55649/Downloads/ANTROPOLOGIA $\% 20 D O \% 20$ CIBORGUE $\% 20$ (4).pdf.

Acesso em 29/04/2019.

HARAWAY, Donna J. Manifesto ciborgue: ciência, tecnologia efeminismo-socialista no final do século XX 
Disponível

em:

< http://www.biolinguagem.com/inuma/HARAWAY $\% 202000 \% 20$ manifesto $\% 20$ ciborgue.pdf

Acesso em: 30/05/2019.

HOBSBAWM, Eric. 1995. Era dos extremos. O breve século XX 1914-1991. 2ªed., São Paulo, Companhia das Letras, 598 p.

HORKHEIMER, Max. Eclipse da razão. 2000. São Paulo, Centauro, 187.

HUXLEY, Aldous. 1937. O despertar do mundo novo. São Paulo, Hemus - Livraria e Editora Ltda.

INSTITUTO BRASILEIRO DE GEOGRAFIA E ESTATÍSTICAS. (IBGE).

2010.

https://pt.slideshare.net/cleoneidebrito/indicadores-sociais-ibge-2010 Acesso 31/02/2019.

INSTITUTO NACIONAL DE ESTUDOS E PESQUISAS EDUCACIONAIS ANÍSIO TEIXEIRA (INEP). (2014). Acesso à $\quad$ informação. Disponível em: < https://pt.slideshare.net/cleoneidebrito/indicadores-sociais-ibge-2010>. Acesso 28/05/2019

JAEGER, Werner. 2001. Paideia: a formação do homem grego. $4^{\mathrm{a}}$ ed., São Paulo, Martins Fontes, 1413 p. KANT, Immanuel. 1986. Sobre a Pedagogia. $3^{a}$ ed., São Paulo, Unep, 2002.

MANACORDA, Mario Alighiero. 2010. História da educação da Antiguidade aos nossos dias. $13^{a}$ ed., São Paulo, Cortez, $455 \mathrm{p}$.

MARX, Karl. 1985. O capital. Crítica da economia política. O processo de produção do capital. $2^{a}$ ed., São Paulo: Nova Cultural, 301 p.

NUNES, Cesar. 1999. As origens da articulação entre Filosofia e Educação: matrizes conceituais e notas críticas sobre a paideia antiga. In: LOMBARDI, José Claudinei. (Org.).

Pesquisa em Educação: história, filosofia e temas transversais. Campinas, Autores Associados, p. 57-75.

MELO, Alexandre de, GOMES, Freitas Paulo \& de OLIVEIRA, Jose Sílvio. (2019). A performance e o conforto térmico nas salas de aulas do centro de ensino médio em periodo integral da escola José Feliciano da Ferreira - Jataí

de GO. Itinerarius Reflectionis, 15(2), 01-08. Disponível em: < https://www.revistas.ufg.br/rir/article/view/58217 Acesso em 30/05/> 2019. Acesso em 29/05/2019. OLIVEIRA, José Sílvio de. 2015. A paideia grega. A formação omnilateral em Platão e Aristóteles. São Carlos, SP. Tese de Doutorado. Universidade Federal de São Carlos. 360 p.

PEREIRA, Paula Cristina. 2011. A condição bumana e a condição urbana. Porto, Edições Afrontamento, 112 p.

REIS, Marcia Santos Anjo. 2013. Educação superior brasileira durante os governos de Fernando Henrique Cardoso (1995-2002) e de Luís Inácio Lula da Silva. In: ASSIS Renata Machado. Educação e cultura: diferentes dimensões. Curitiba, CRV, $212 \mathrm{p}$.

SANTOS, Boaventura Sousa. 2013. Se Deus fosse um ativista dos direitos humanos. Coimbra: Edições Almedina, 194.

SAVIANI, Demerval. 1990. Contribuições da filosofia para a educação. In: Em Aberto. Contribuições das Ciências Humanas para a Educação. 9 (45) 1-72.

2007. O Plano de Desenvolvimento da Educação: Análise do Projeto fazer MEC. Educ. Soc. [online]. 28 (100): 1231-1255. Disponível em: < http://www.scielo.br/pdf/es/v28n100/a2728100.pdf $>$ Acesso 04/03/2019.

ZAINER, Josiah. Diy buman crispr guide. Disponível em : < $\quad$ http://www.theodin.com/diyhumancrispr/?fbclid=IwAR2WoSK3tKadCT0HbMgZ80sadCKnzzFbnNz-

zSaV7IQlhmD-Az5rKyLm11E >. Acesso em 29 - 05 - 2019.

ZAINER, Josiah. Diy crisp genome engineering <https://www.youtube.com/watch?v=TWthRz-0T18 $>$. Acesso em 29-03-2019. 